\title{
A Study of British and American Literature Education Goals Based on Humanistic Quality
}

\author{
Wenjing Wang ${ }^{1}$ \\ ${ }^{1}$ School of Foreign Languages, Inner Mongolia University for the Nationalities, Tongliao, China \\ Correspondence: Wenjing Wang, School of Foreign Languages, Inner Mongolia University for the Nationalities, \\ Tongliao, China. E-mail: wangwenjing128@163.com
}

Received: April 2, 2015 Accepted: April 28, 2015 Online Published: May 31, 2015

doi:10.5539/ells.v5n2p160 URL: http://dx.doi.org/10.5539/ells.v5n2p160

\begin{abstract}
Along with the reform of education system, the British and American literature teaching also shows the corresponding changing, especially in order to achieve the corresponding education target step by step as the teaching key point. In the process of achieving British and American literature education goals, the teacher analyzes not only the specific contents of British and American literature education goals, but also the specific ways of achieving education and evaluation system as for the corresponding summary analysis, so as to improve students' understanding ability of British and American literature.
\end{abstract}

Keywords: humanistic quality, British and American literature, education goals, study, assessment

\section{Introduction}

Humanistic quality refers to the humanistic spirit and the comprehensive quality which are reflected from the knowledge of humanities possessed by the people themselves. Therefore, humanistic quality education is related to their own practice, environment edification and humanistic knowledge, converting the human outstanding culture achievements into their own culture, temperament and personality, thus to become people's internal and stable quality. "The outline of college English teaching for English major" depicted in British and American literature teaching goals focuses on cultivating students' ability to understand, appreciate and read the original in English, and at the same time requires students to grasp and understand the basic knowledge of the literary criticism and the corresponding methods. By asking them to implement the ability of reading and analyzing related to British and American literature, improve the students' basic language work and humanistic quality, and at the same time strengthen their understanding of western culture and literature. In British and American literature education, only with the combination of humanity quality education can the goals of British and American literature education system be realized.

\section{The Specific Contents of British and American Literature Education Goals}

By and large, education goal refers to educators looking forward to the situation of development in advance after accepting the relevant education. Educators should not train a certain particular skill separately but design British and American literature goals scientifically. The education goals of British and American literature mainly contain the aspects of basic knowledge, ideas and values, behavior, etc. From the dimensions, British and American literature education goal is consisted of aesthetic quality, information quality, scientific quality, moral quality and cultural quality, etc, each dimension including their own idea, behavior, common sense and other factors. The cultural quality, which is only a part of the humanistic quality, is not the humanistic quality. British and American literature course is not only the carrier of the relevant knowledge but also a synthesis of consciousness, behavior and knowledge (Jiang, 2012). Therefore, British and American literature education goals contain not only the basic knowledge but also the corresponding ideas and methods, each level including the cultural quality, the moral quality, the scientific quality, the information quality, the aesthetic quality and the goal of quality education. Only with the combination of British and American literature education and humanity quality education can the goals of the British and American literature education system be realized.

There are the cultural education goals in British and American literature course. The cultural education goals mainly contain culture knowledge, cultural concept and cultural behavior, etc. Culture knowledge, namely, the close linking between the literature and people's actual life, can perform the corresponding differences , 
understand the literary genre and the basic form and grasp the basic content of the literature. Cultural concept, that is to say, British and American literature has an important guiding role for people's life. People should learn to distinguish essence from scum. Cultural behavior, in other words, is a behavior to appreciate literary works actively, to evaluate it accordingly, to create and spread it. Through the culture behavior, literature can express social phenomena and people's inner feeling. From literary works it is necessary to satisfy one's spiritual wealth and power.

There are science education goals in British and American literature curriculum. Science education goals mainly refer to scientific knowledge, scientific ideas and scientific behavior. Scientific knowledge means mastering the basic knowledge and knowing the new research results and fresh knowledge in the literary field. Scientific ideas are to fully realize the importance of learning British and American literature. Scientific behavior is to guide studying behavior according to the scientific rules in the process of studying.

There are information education goals in British and American literature course. Information education goals mostly include information knowledge, information ideas and information behavior. Among them information knowledge is to know about the main source and relevant channels of certain information together with the web sites often used in the literature research field. Information ideas are that students should be aware of the importance of integration into the information society. Information behavior is to retrieve the gained information relevantly.

\section{The Ways of Implementing British and American Literature Education Goals}

In order to implement British and American literature education goals better, the following aspects should be started.

Firstly, improve students' reading experience about British and American literature works. Teachers can give the reading process of British and American literature to students and let them gradually cultivate interest in literary appreciation and judgment through their own hands-on experience of British and American literature classics. Literature can model a related image through the means of language in order that it can express the author's thinking about the social life. Literary works contain the author's attitude, thought and consciousness about life. British and American cultural consciousness is the important way to know about the western culture. British and American literary works abound in rich local conditions and customs, history and culture, language phenomenon. When they are reading these relevant literary works, students can appreciate the author's writing characteristics, superb rhetorical devices and excellent language skills. As readers students can really understand the works and the cultural phenomenon that is reflected in the works only through the combination of the personal experience and feelings about life with the author's spiritual communication in the works. Therefore, the teacher should take the inspiring and leading ways in teaching to arouse students' enthusiasm to participate in the process, to mobilize students' emotional reactions, to put students in the feeling and experience. In this way students can learn knowledge from the literature works, experiencing life and improving their appreciation ability. At the same time, to enhance the intuitive felling, the teacher also may guide students to take full advantage of the web resources to enjoy the films adapted according to the British and American literary works (Nie, 2011). Furthermore, reading a lot of the original works in English can make students' English level higher.

Secondly, strengthen students' basic knowledge of British and American literature, which is a knowledge level based on the rational cognition. Its focus is to make students understand the general situation of the development of British and American literary history and context, the important literature phenomenon in the development of British and American literature, genre, works and writers, thus to obtain the basic knowledge of English and American literature (Fan \& Rui, p. 151). In the class, the teacher should teach some language knowledge about English and American literature, introduce the writing background, explain literary terms, analyze the theme of literary works and enforce students' basic knowledge of British and American literature. Teachers can constantly supplement the teaching contents of British and American literature, choosing the works full of era characteristics and reflecting the characteristics of times. Teachers ask students to come into contact with more classic and contemporary English literature and at the same time select the suitable material based on the level of students' reading and appreciating. British and American literature course is not only a single language skills teaching, which should be converted to colorful and rich teaching contents. Teachers can attract students with excellent literature works and penetrating humanistic thought and wisdom, cultivating their solid and fundamental language skills through literature study.

Thirdly, increase the interpretation of basic theory of literary criticism and the corresponding analysis method, which is a kind of aesthetic level based on the speculative theory. Its emphasis is to help students master the basic knowledge of literary criticism and analysis method through the introduction to literary criticism and 
method, through the concrete instance analysis of literary works, then to improve students' theory training and thinking ability (Fan \& Rui, p. 151). Just as professor Wang Shouren thinks that British and American literature curriculum is a quality training course. Students actively participate in the process of text meaning to look for, find and create, developing a keen perception gradually, mastering the rigorous analysis method and forming the accurate expression way. The feeling from the rich perceptual experience up to the rational knowledge, analysis and presentation skills will benefit students a lot (Wang, pp. 10-11). When teaching British and American literature, teachers should not only put the specific knowledge to students, but also broaden students' horizons, expand their thinking and introduce the basic theory of literary criticism and the corresponding analysis method. Teachers are supposed to ask students to understand the important literature phenomenon, genre, works, and writers in the development of British and American literature criticism, thus get them to obtain the basic knowledge of English and American literature.

Fourthly, cultivate students' aesthetic consciousness and moral consciousness. In the process of teaching British and American literature, the teacher should be timely to work to make the corresponding moral judgments, advocating the true, the kind and the beautiful, lashing the false, the evil and the ugly, to cultivate students' aesthetic consciousness and moral consciousness. The teacher has the responsibility to make students feel life and have an insight into the meaning of life. The teacher also has to cultivate their humanistic feelings and make public of humanism spirit. Its key point is to help students to edify sentiment, expand their horizons, know life and enrich the spiritual cultural life. Literature contains wide-ranging themes which can not be substituted by any other aspects of learning in expressing enlightenment and reflecting on the value of life. In addition to that, foreign literature is also the real and unavoidable path to learn English well (Yu, pp. 7-8).

Fifthly, cultivate students' intercultural communication consciousness and ability. Reading appreciation and understanding about British and American literature works is a form of intercultural communication. Literature is the important carrier of culture and the important manifestation of national personality (Fan \& Rui, p. 151). It is an effective teaching way to know about British and American culture by the means of British and American literature, and then to competent the intercultural communication. The aim is to broaden students' cultural vision and thoughts, at last to improve the comprehensive humanistic quality.

\section{To Perfect the Related Evaluation Systems in the Process of British and American Literature Teaching}

The realization of the goals is the key factor to determine success or failure of a target, so it's necessary to gradually perfect the evaluation system in British and American literature teaching.

\subsection{Summary Assessment}

The so-called summary assessment generally refers to implementing the unified exam which is a required test form after finishing learning British and American literature course. This assessment mainly inspects students' understanding and mastering about the basic knowledge of British and American literature, to promote students to memorize the related knowledge information accordingly, thus to realize the education goal of British and American literature better (Zhou \& Han, 2009). The summary assessment helps fully to see whether students master the basic content of literary works, literary genre and basic form, the new findings and research methods appeared in the literary field. However, the form of the test for request itself has defects that students learn something by rote and study right before the test. Although they can not understand the basic knowledge of British and American literature truly, they still can get better scores. Furthermore, the time of summary assessment is shorter and it is impossible to fully inspect students' qualities about culture, moral, science, aesthetics and information within two or three hours. Therefore, the exam of British and American literature course can not only stay in a comparatively single assessment mode. It is necessary to enrich the test methods of British and American literature course. Facts have proved that the traditional paper assessment test method obviously cannot evaluate the real condition of British and American literature teaching comprehensively. This test method even cannot reflect students' mastery of the course more accurately. In a sense, it can only reflect a part of students' rote learning ability or the test ability. Changing scores as the only evaluation criteria of traditional summary evaluation methods is more comprehensive and diversified pattern of formative assessment, which is beneficial to improve the effect of this course and more conductive to the improvement and development of the process of teaching and learning.

\subsection{Formative Assessment}

The so-called formative assessment usually refers to implementing investigation form at any time in the process of British and American literature learning to check students' learning situation at every stage (Xueli, 2012). The advantage of this assessment form is mainly embodied in the following aspects. First of all, this evaluation way which lasts for a long time can assess students' comprehensive quality accordingly, relatively and objectively. 
Secondly, the form of this evaluation is flexible and various. For example, letting students write the related experience and feeling according to the learning contents after class so as to deepen students' understanding about what they are learning. Ask students to write papers related to British and American literature course. Ask students to write the comment about learning British and American literature or require them to present their oral reports in class. Students can express their views and understanding about British and American literary works through appropriate ways. In the paper writing of British and American literature, students are required to collect, sort out and organize a large amount of related information with British and American literary works so as to investigate students' information quality well. In addition, in the process of writing papers of British and American literature, students will employ the scientific method and on the basis of this to check students' scientific quality. The paper writing of British and American literature requires students to actively participate in the the process of looking for, finding and creating the meaning of related test. This process can gradually cultivate students' keen perception and scientific and careful analysis method of the text, eventually to form relatively correct and scientific expression way. At last, it is flexible to choose time in this form of evaluation. For example, whenever the students learn a writer's literary works, the teacher can compare and analyze the writer's works created in different times or the different styles in the same period. Through the students' own internalized behavior, the teacher lets them know about the culture knowledge of British and America in a certain degree. On the basis of that, making a corresponding contrasting analysis, students can obtain a certain cultural approval and recognition.

Teaching evaluation is one of main ways to verify students learning outcomes and at the same time the key factor to reflect the teaching effect. So it is a necessity to explore a new teaching evaluation method actively. Through the implementation of process evaluation, pluralistic evaluation and timely evaluation, the combination of summary assessment with formative assessment, a new teaching evaluation can be formed. When the evaluation systems are used to evaluate, the relationship between different evaluations should be coordinated effectively to play the real efficacy of evaluation system.

\section{Conclusion}

In the background of humanity quality education, British and American literature education is facing severe challenges. The related departments and education staff should face up to this kind of phenomenon, adopt corresponding strategies to cope with the challenges and arrange the course reasonably. In the process of realizing the goals of British and American literature education, the teacher not only analyzes the specific contents of the British and American literature education target but also the specific way and evaluation system to make the education target come true, thus to improve students' understanding of British and American literature. The rich style and vivid language material mentioned in the literature course in different extent can stimulate students' interest in learning, enhance the initiative of learning and improve the cultivated humanities. Let students fully understand the pleasure of English language application in creating literature, thus to strengthen the teaching of British and American literature, to promote the development of English education, to realize the ultimate goal of cultivating high-quality talents, when they are learning British and American literature and understand English and American culture. In shorts, by setting up the British and American literature class, its ultimate purpose is to guide students to correctly understand the similarities and differences between Chinese and western culture and literature, to help students build up the correct world outlook, the outlook on life and values.

\section{References}

Jiang, D. L. (2012). British and American Literature Education Goals under the Background of Humanistic Quality Training. Journal of ChiFeng University.

Nie, X. X. (2011). On the Function of British and American Literature Teaching in the University Students' Humanistic Quality Training. Literature Education.

Fan, Y., \& Rui, Y. P. (2005). The Goal Connotation and Level Localization of British and American Literature Teaching. Foreign Literature Study.

Wang, S. R. (2002). A Farewell to the Model of Literary History+Selected Readings. Journal of ZhengZhou University.

Yu, J. H. (2002). Study to Know: The Supreme State of Learning. Journal of ZhengZhou University.

Zhou, Z. G., \& Han, K. (2009). British and American Literature Teaching Learning and University Students' Humanistic Quality Training. Journal of LiaoNing School of Administration. 
Xue, L. (2012). British and American literature Teaching Learning and Students' Humanistic Quality Training in English Major. Journal of QiQiHaEr University.

\section{Copyrights}

Copyright for this article is retained by the author(s), with first publication rights granted to the journal.

This is an open-access article distributed under the terms and conditions of the Creative Commons Attribution license (http://creativecommons.org/licenses/by/3.0/). 